\title{
Historein
}

Vol 16, No 1-2 (2017)

Greek Historiography in the 20th Century: Opening a Research Agenda

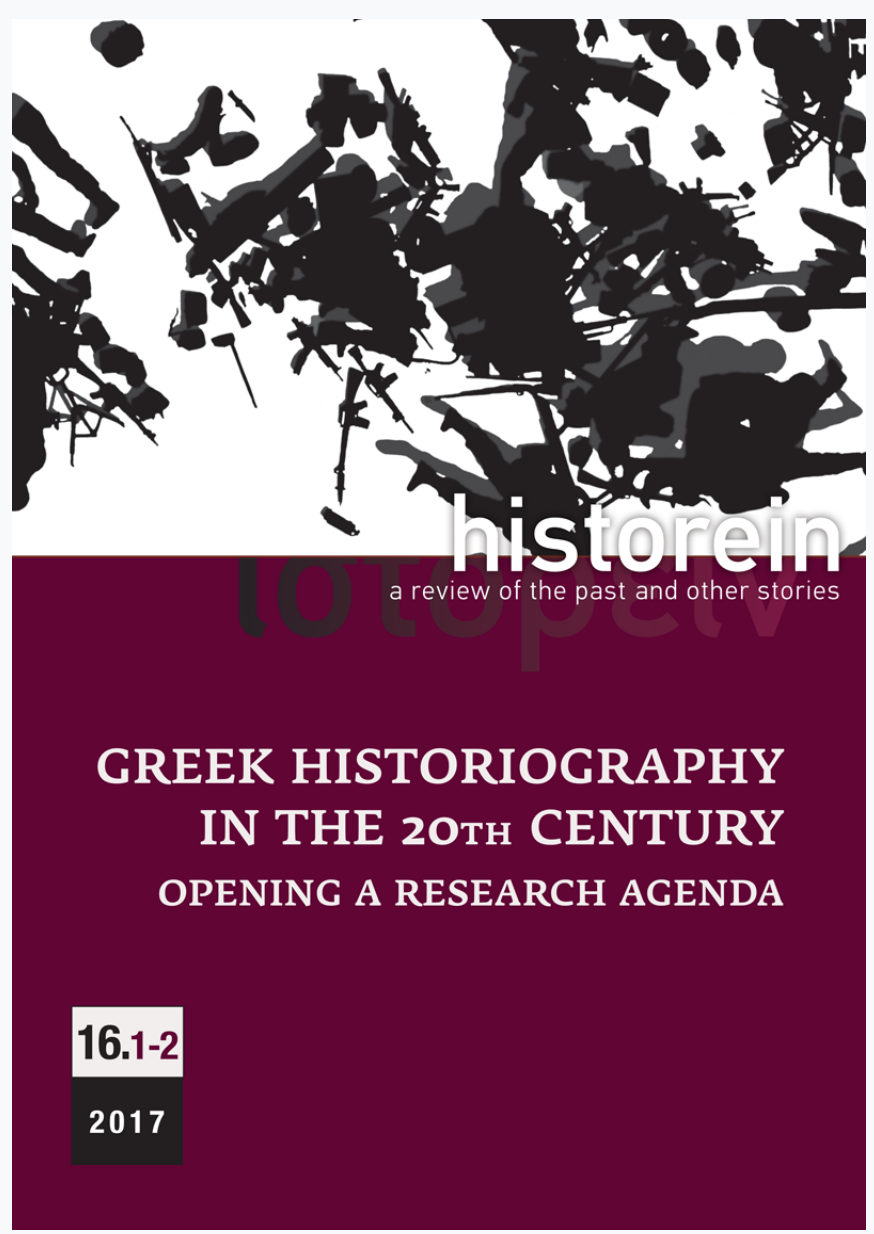

\section{Gender in modern Greek historiography}

Nikolaos Papadogiannis

doi: $10.12681 /$ historein. 8876

Copyright $\odot$ 2017, Nikolaos Papadogiannis

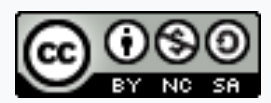

This work is licensed under a Creative Commons Attribution-NonCommercialShareAlike 4.0.

To cite this article:

Papadogiannis, N. (2017). Gender in modern Greek historiography. Historein, 16(1-2), 74-101. https://doi.org/10.12681/historein.8876 


\section{Gender in modern Greek historiography}

Nikolaos Papadogiannis

Bangor University
Historian Rüdiger Hachtmann has described the history of tourism in Germany as a "small wallflower with a future".' He wishes not only to stress its remarkable potential to develop but also the difficulties faced by scholars who engage with it. This metaphor also beautifully demonstrates the condition of gender history in Greece, especially given its capacity to help in the reconsideration of deeply entrenched historiographical assumptions.

This article analyses the diverse and shifting approaches to gender in the historiography of modern Greece, a term which is used interchangeably in the article with modern Greek historiography. Some clarifications from the outset are necessary, however, concerning the scope of my analysis. The article addresses historians who were at a point linked to Greek academia, as students, members of staff or who might have worked on the history of Greece in the late modern era while based in non-Greek academic environments. In so doing, the article addresses works in which Greece is considered in some way: as a context where shifting gender relations have unfolded; and/or where representations of Greece/Greekness and their gender connotations are studied. The analysis also includes Greek diasporic identities where these have been studied in relation to gender. However, I probe the extent to and the ways in which historians who have dealt with these identities regard them as part of the history of modern Greece. In dealing with these settings, I concentrate on the late modern era, namely from the late eighteenth century onwards: I do not regard the modern Greek state or the Greek national identities that emerged in this period as a continuation of polities and identities that had existed beforehand. 
Moreover, given the interdisciplinary character of many works addressing gender, discerning which of them fall squarely into the category of historical research is a considerable challenge. I have thus tried to follow a broad understanding of the latter concept to include the works of all those scholars who describe themselves as historians. Nevertheless, the article tries to illuminate the extent and the ways in which interdisciplinary debates have affected their work. Furthermore, since the works analysed here do not fit neatly into a women's/gender history dichotomy, as I mention below in detail, I use the more inclusive term "gender history" for all of them, highlighting, simultaneously, those works that focus on women. Finally, the article refers to the entirety of historical research that considers gender, regardless of whether the latter plays the central or a peripheral role in these analyses. In so doing, it considers published monographs, edited volumes, journal articles and book chapters. Furthermore, it refers to a few unpublished PhD theses that have made a significant contribution, in my opinion, to the study of modern Greece from the perspective of gender.

The article draws extensively on the arguments put forth in older and extremely illuminating reviews of gender in Greek historiography, authored by Efi Avdela as well as by Eleni Fournaraki and Yannis Yannitsiotis. ${ }^{2}$ Resonating with Avdela in particular, it demonstrates that the study of gender in Greek historiography has dealt extensively with middle-class women and female labour. ${ }^{3}$ The article wishes to complement these analyses, however. It discusses thoroughly relevant studies that have appeared since Avdela's, Fournaraki's and Yannitsiotis' articles were published. Moreover, these reviews focus on historical research on modern Greece which has been conducted by scholars based in Greece. In considering these additional works and in reassessing those addressed by Avdela, Fournaraki and Yannitsiotis, this article aims to make a contribution by analysing in more detail the ways in which the scope of gender history research regarding Greece has expanded in recent decades: it shows in particular that gender is being increasingly examined in interplay not only with social class, but also with age, a parameter that is not addressed in the aforementioned reviews. Moreover, while Avdela pointedly remarks that historical research has neglected family relations in rural Greece, ${ }^{4}$ I wish to demonstrate that this situation has started to change: modern Greek historiography dealing with gender has recently but slowly started to explore contexts beyond urban centres, such as small provincial towns and rural areas. Finally, while Avdela correctly mentions that very few works on gender history written in Greece take a transnational perspective, ${ }^{5}$ this article aims to show that there has been change also in this respect and that there has been a clear increase in transnational approaches to historical research on modern Greece that considers gender.

The article proceeds in five steps. After briefly addressing the importance that has been assigned to the study of gender in modern Greek historiography, it goes on to examine the ways in which gender has been studied from the perspective of social sciences and humanities internationally, while also probing the echoes of such shifting approaches to research on Greece. Sections three, four and five analyse developments in the main themes addressed by works dealing with gender: middle class; labour relations; and the expansion of the scope of gender beyond urban centres as well as its growing interest in the intersection of gender and age. 


\section{The importance assigned to gender in modern Greek historiography}

The first books on the history of gender were authored in Greece in the nineteenth century. ${ }^{6}$ However, the emergence of historical research on gender within the framework of modern Greek historiography is indelibly linked to the feminist movement of the 1970s and 1980s. At that point, several feminist magazines and student groups appeared: autonomy was a rallying cry for them, conceptu-

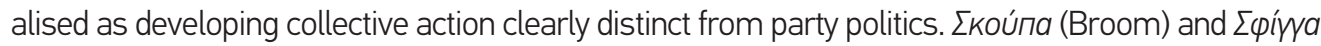
(Sphinx) were among the publications, which in general proved to be short-lived. Feminist work was

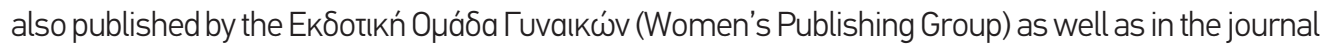
Aivn [Whirlpool, published from 1986 to 2005]. Feminist student groups were created at numerous academic units in Athens, such as at the law, philosophy and agriculture schools of the University of Athens, as well as at its medicine and biology departments. The autonomous feminist movement remained active until the mid-1980s. ${ }^{7}$ Most autonomous feminists were university students or alumnae, some of whom had studied abroad. Some of those autonomous feminists, such as Avdela and Angelika Psarra, who have played a prominent role in the study of gender, studied in France and were influenced not only by its women's liberation movement but also by the academic environment. ${ }^{8}$

The 1970s and 1980s were an era that witnessed significant changes in modern Greek historiography broadly, which were due to developments in research on Greece in general and Greek historiography in particular after the collapse of the Greek military junta in 1974. What followed was a proliferation of studies by historians and social scientists, whose main theme was what they viewed as Greece's particular encounter with modernity, namely one which differed from that which had transpired in other parts of Europe. ${ }^{9}$ Characteristic publications included the work of sociologists Constantinos Tsoukalas and Nicos Mouzelis as well as historian George Dertilis. ${ }^{10}$ Among the main points raised by these publications were: the adoption of the "centre-(semi)periphery" scheme, which some of these scholars employed to prove the dependence of Greece on advanced industrialised societies; the thesis that no significant industrialisation occurred in Greece along the lines of other European countries, which resulted in no clear demarcation of social class boundaries, at least in the nineteenth century; and the extensive use of the notion of clientelism, ${ }^{11}$ which these works depicted as the main path through which the rural masses accessed the bureaucratic mechanisms of the state. ${ }^{12}$ Overall, while these scholars did not always agree on the specific concepts they used and the particular conclusions they reached, they believed that Greece's path to modernity was marked by "absences" and "distortions".13

The 1980s also witnessed the emergence and rise to prominence of the "new history" that also addressed issues touched on by the abovementioned studies, such as the extent to which Greece was industrialised. ${ }^{14}$ Historians subscribing to this approach delved into economic history, aiming to examine closely financial structures. "New history" flourished in research centres funded by the National Bank of Greece and Commercial Bank of Greece as well as in new regional universities that were established in the 1980s. ${ }^{15}$

The relationship between gender history and "new history" was a difficult one: in the "new history" paradigm, which was gaining momentum in Greek academia, gender appeared to be of secondary importance. ${ }^{16} \mathrm{As}$ a result, the rising prominence of this paradigm contributed to the marginalisation 
of the study of gender at Greek universities. Quite tellingly, between 1985 and 1995, six books on gender history were published by scholarly institutions, which were not, however, formally linked to Greek universities. ${ }^{17}$ Nevertheless, the production of "new" and gender history was not mutually exclusive: an article by Avdela on gender history appeared in a volume co-edited by Hadziiossif on bourgeois modernisation in early twentieth-century Greece. ${ }^{18}$ Moreover, some of the aforementioned institutions that published works on gender history, such as the Foundation for Research and Education of the Commercial Bank of Greece, also promoted "new history".

The 1990s heralded an era of stagnation in the study of gender in modern Greek historiography, a fact linked to the closure of the aforementioned institutions that had supported historical research on gender. Since the end of that decade, however, the situation has improved, with gender attracting increasing attention, marked by the significant increase in the number of publications dealing exclusively or to an extent with gender history. The same applies to $\mathrm{PhD}$ dissertations taking the perspective of gender history. ${ }^{19}$ In addition, chapters dedicated to gender history have been appearing in "so-called general historical works". ${ }^{20}$ The establishment of undergraduate and postgraduate programmes dealing with gender history in Greek academia has certainly contributed to this diffusion. One such course is the EU-funded interdisciplinary MA programme "Women and Genders: Anthropological and Historical Approaches" of the Department of Social Anthropology and History at the University of the Aegean. In the meantime, the creation in 2007 of the Greek National Committee of the International Federation for Research in Women's History has further encouraged the study of gender in modern Greek historiography: for instance, it organised the first conference ever held in Greece that was dedicated to gender history. ${ }^{21}$

This tendency has been assessed in different ways, though: according to Avdela, gender is still largely assigned a marginal position. ${ }^{22}$ By contrast, Fournaraki and Yannitsiotis claim that since the late 1990s a "dynamic process of diffusion of women's and gender history in [Greek] historiographical production as a whole" has transpired ${ }^{23}$ Indeed, the study of gender has contributed to the reconsideration of historical research on a growing number of topics; gender is used as an analytical category in studies which are not primarily presented as gender history, as is shown in the following sections in detail. Nevertheless, there are still limits to this diffusion. I would concur with Avdela that it is cultural historians that aim to render their work more complex by taking gender into account, as the following three sections make clear. Several historiographical fields seem to largely ignore gender representations and practices. A prominent case in point is diplomatic history. While a new diplomatic history that has emerged in "western" academic environments aims to consider, among others, the allocation of gender roles among policymakers as well as how gendered stereotypes and assumptions influenced their decisions, such reflection has not made headway in modern Greek historiography. ${ }^{24}$ Similarly, with the exception of the work of Margarite Poulos, which is mentioned below, military history has mostly neglected gender in Greek historiography. Therefore, the argument of gender historians that gender is an analytical category that can be used to approach all historical topics and fields has not found resonance with all historians dealing with Greece. ${ }^{25}$

The article shall now turn to examine the concrete ways in which gender has been studied in international historiography and extent to which such endeavours have affected modern Greek historiography. 


\section{From women to gender and beyond in international scholarship}

In the 1960s and 1970s, women's history gained momentum in the "west", where it was linked to the diffuse radicalism of that era, especially the women's liberation movement. ${ }^{26}$ The roles assigned to women in modern western societies were linked to biological characteristics; thus, the dominant view in the west portrayed their identity as uniform, regardless of specific context and era. History was confined to the action of men. Women's history, by contrast, aimed to challenge these assumptions by rendering women visible historical subjects. Its point of departure was to shed light onto the experiences that women shared. ${ }^{27}$

While women's history has followed several paths, it has largely pivoted in Britain, the US, Italy and France around the metaphor of separate spheres. Carroll Smith-Rosenberg's essay "The Female World of Love and Ritual" proved influential in this field. She claimed that the acute distinction of gender roles in the US during the nineteenth century led to the emergence of a homosocial female world. Other US historians, such as Nancy Cott, built on this idea, arguing that a separate domestic female sphere was the site of feminist identity making. ${ }^{28}$ The separate spheres metaphor continued to influence various historians even in the 1990s and 2000s, remaining particularly popular among Italian and German feminist historians. ${ }^{29}$

The body of scholarship pivoting around "women's culture" sometimes reverted to ahistorical and essentialised notions of gender, reproducing binary distinctions between "men" and "women", approaching their relations in a static way and utilising different categories and asking different questions about each. Despite the enduring popularity of the separate spheres metaphor and the "women's culture" argument among some feminist scholars, however, historians since the late 1980s have dealt more and more with gender relations rather the history of women. Gender historians increasingly focused on the discursive and shifting constructions of femininity in relation to masculinity. They probed the mechanisms that shaped and reproduced gender difference. ${ }^{30}$ In adopting such an approach, some gender historians were influenced by poststructuralism and the "linguistic turn". Those historians aimed to challenge "grand narratives" that approached femininity as a fixed position and underplayed the diverse and shifting meanings attached to gender. A prominent case in point is Joan Wallach Scott. In her pathbreaking 1986 article "Gender: A Useful Category of Historical Analysis", she claims that historians should place emphasis on "how the subjective and collective meanings of women and men as categories of identity have been constructed". In this vein, she stresses the need to situate "gender" in a broader context with regard to issues of power, scrutinising how gender was constructed in and affected by economic and political institutions. Her definition of gender thereby encompassed four interrelated elements: symbolic representations; normative concepts; political and social institutions; and subjective identity. ${ }^{11}$ Philosopher and gender theorist Judith Butler has also been a pioneer of the combination of feminism and poststructuralism. In her book Gender Trouble, which has been influential among historians as well, she argues against the distinction between (biological) sex and (cultural) gender, claiming that sex is yet another cultural construction. ${ }^{32}$

The transition from women's to gender history was also facilitated by research addressing masculinities in relation to femininities. The work of sociologist Raewyn Connell has been trendsetting 
in this sense since the 1980s. Connell has constantly revised her approach to gender and, along with James Messerschmidt, published relatively recently an updated outline for a comprehensive approach to masculinities, where she incorporates some of the criticism that has been voiced against her work. They argue that the model of hegemonic (and complicit) masculinities has been formulated in tandem with desirable or "emphasised femininities", in opposition to subordinated masculinities. ${ }^{33}$ They stress that "hegemonic masculinity" should not be approached in a "statistical sense", ${ }^{34}$ nor as a fixed notion, but rather as a malleable one, to which the women's liberation movement, the emergence of models of "managerial masculinity" and intergenerational conflicts in migrant communities, among other factors, contribute. Since the late 1980s and early 1990s, historians have also shown growing interest in the making of masculinities..$^{35}$

Meanwhile, gay and lesbian history also began to develop in the late 1970s and early 1980s due to the activity of the homosexual liberation movement and the growing academic interest in the history of sexuality. ${ }^{36} \mathrm{As}$ the 1980 s progressed, relevant research began to question whether it made sense to refer to "gays" and/or "lesbians" prior to the creation of communities or the emergence of individuals that employed those terms. Treating such an approach as "ahistorical", a growing number of scholars, at least in North America and Western Europe, have probed the complex ways in which sexuality and gender are performed, how homosexuality is produced as deviant and how the normative discourses lambasting homosexuality have been resisted. In this vein, they have scrutinised whether homoerotic sexual behaviour was necessarily tantamount to a single (homo) sexual identity. Challenging this assumption, Martha Vicinus, an expert in English, women's studies and history, examines educated Anglo-American women who developed erotic friendships with other women, while often flirting with men as well, between 1778 and 1928. ${ }^{37}$ Vicinus argues that these women "fashioned recognisable sexual identities". She thus seeks to uncover their "complex identifications, embedded in class, national and racial associations" ${ }^{38}$ Other scholars who critically interrogate what they view as "ahistorical" approaches to the terms "gay" and "lesbian" have stressed the need to construe such identities not only as complex but also as unstable. They tend to be influenced by poststructuralism and, especially, the work of Butler, usually defining themselves as subscribing to "queer theory". ${ }^{39}$ In any case, the relationship between developments in gender history and in the study of gay, lesbian and queer subjects is complex: historian Jeanne Boydston claims that, despite her intentions, Scott did not avoid conceptualising gender as a set of fixed oppositional categories, juxtaposing men with women. Thus, Boydston maintains, Scott failed to pave the way for the study of subjects with gender identities that do not fit neatly into the male versus female taxonomy. Boydston has recommended that historical research considers the diversity of both sexuality and gender, one that moves beyond the male versus female as well as the homosexual versus heterosexual taxonomies, but also the complex links between various genders and sexualities. ${ }^{40}$

"Gender", as defined by historians in the 1980s, has come under fire for another reason: in trying to render their work more nuanced, gender historians have also addressed the interweavings of gender, social class and race from the mid-to-late 1980s. ${ }^{41}$ Nevertheless, some of their fundamental propositions at that point appeared to undermine this aim. In particular, as Boydston aptly remarks, by arguing that "gender is a primary way of signifying relations of power", Scott "virtually ruled out (as naive) distinctions between male and female that might not be about this kind of differentialising 
power".42 The issue whether gender is necessarily a primary principle of social classification was particularly propelled into the limelight by feminists who were "women of colour". Such scholars argued that the western feminist vision, which also informed women's history, was too narrow to analyse the status of women of colour in the west as well as the oppression of women in the Third World. Some of them went further to challenge whether women's oppression may necessarily be associated with gender. ${ }^{43}$ In this vein, they stressed the importance of "race" as a system of meaning based on and reproducing power relations.

In general, the ways in which historians in the west approach gender have been diversifying since the 1980s. In assessing this process, historian Sue Morgan has argued that relevant historians have shifted from a history of subjects (namely women) to a history of (gender) relations. ${ }^{44}$ Nevertheless, it might be inaccurate to an extent to discern such a linear transition in international historiography and in the humanities in general, as anthropologists Venetia Kantsa and Evthymios Papataxiarchis aptly remark. An acute distinction between women's and gender history would obscure the fact that the several methodological concerns voiced by scholars analysing gender actually date back to 1970 s research. ${ }^{45}$

All the aforementioned shifts in the approaches to gender at the international level have influenced several fields of the humanities and the social sciences in Greece, but in different ways and to a different extent. According to a categorisation offered by Kantsa and Papataxiarchis, the social sciences and humanities in Greece can be classified into three categories as regards their approach towards gender. Kantsa and Papataxiarchis argue that in the fields of sociology of education, political science and economics (especially in relation to work), scholars in Greece continue to analyse "women", neglecting all efforts to de-essentialise conceptualisations of gender that have developed internationally since the 1980s. In the fields of linguistics, psychology and architecture, only a limited number of scholars show a keen interest in gender. Finally, historians and social/ cultural anthropologists have been receptive to shifting developments towards gender at an international level. ${ }^{46}$ The article shall now turn to modern Greek historiography that has considered gender since the 1980s, discussing in detail the topics it has dealt with as well as its methodological approaches. It will show the extent to and the ways in which the historians involved have been affected by shifting approaches to gender in the west.

\section{Gender and the middle class}

The first works on gender history in modern Greek historiography focused on women as subjects of history, studying the action of specific individuals or groups of women. Nevertheless, in contrast to what Morgan argues and lending support to Kantsa and Papataxiarchis' assertion, this was no history of subjects as opposed to a history of relations, but one that combined both: the initial approaches to gender considered, simultaneously, the (re)shaping of the relations between women and men. In this respect, the study of the interconnections between gender and social class has been a leitmotiv since the 1980s in the work of gender historians studying modern Greece. In the 1980s they evinced significant interest in the gender and social class identities of what could broadly 
understood as middle-class women and their activity from the second half of the nineteenth century to the outbreak of the Second World War. They introduced a novelty in the study of the middle class in general by examining the practices that shaped middle-class subjects in Greece. ${ }^{47}$

In embracing such a perspective, several ground-breaking historical analyses of gender explored individual and collective subjects involved in women's protest. Noteworthy in this respect is the work of Eleni Varikas. She shared the aim of the feminists of the 1970s and 1980s to demonstrate that women's subordination to men appeared in specific social cultural contexts and was not bereft of contes-

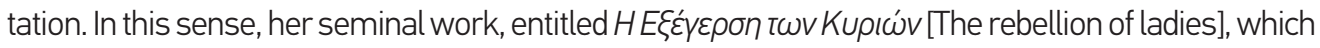
was published in 1987 by the Foundation for Research and Education of the Commercial Bank of Greece, addresses women's mass mobilisation in Greece from 1833 to 1907, focusing particularly on the 1870s onwards. Two questions figure prominently in her analysis: first, whether the emergence of feminism in nineteenth-century Greece was merely the outcome of a mimesis of trends flourishing elsewhere in the west or whether it should be attributed to domestic factors. Given the fact that the women's liberation movement of the 1970s and 1980s in Greece was accused by its opponents of simply imitating foreign trends, Varikas was keen to clarify that this was not the case, not just for the Greek feminists of that era, but also for those of the late nineteenth and early twentieth centuries. The second issue that Varikas stresses is associated with a divergence between Greek feminists of the late nineteenth century and of the subsequent decades: how was it possible that they managed to employ an ardently nationalist rhetoric while subscribing to an internationalist feminist cause?

In this work, Varikas probes how women developed gender consciousness. Avoiding a narrow interpretation of Marxism, she does not seek to discern types of "false consciousness" as opposed to the feminist consciousness. By contrast, she seeks to analyse how women made sense of their gendered experience. In a sense, her way of approaching "consciousness" resembles the concept of "identity". Her analysis particularly highlights the doctrine of equality in difference, which middle-class men formulated in the mid-to-late nineteenth century. This drew on two assumptions: first, that men and women were essentially different in biological terms, which, however, also affected their behaviour in general. In this allocation of roles, femininity was linked to emotion. The second assumption rested on a separation of the "public" from the "private" sphere, confining women to tasks associated with the latter. In this vein, women were not officially proclaimed to be inferior to men, but merely different, although such difference was certainly not free from gender hierarchies: positions of power were reserved for men. Still, women were expected to play a pivotal role in Greek society: they were assigned the duty to nurture the male patriots and fighters whom the dominant irredentist Grand Idea expected to "liberate" Greek lands from foreign rule. Women were supposed to accomplish this task as mothers: it became increasingly legitimate for middle-class women to engage in specific activities in the "public sphere", which was regarded as an extension of their maternal role, that reflected what they did in the "private sphere". Thus, they could become teachers or philanthropists, contributing through such activities as instilling patriotic ideals or caring for men who had taken part in wars against enemies of the nation, such as in 1897. In this respect, Varikas' book is also original for shedding light on political activity before women were granted the franchise in Greece. Varikas has also enriched mainstream political history in Greece by analysing forms of political activity that, given the focus on political parties and workers' protests, it has neglected. ${ }^{48}$ 
Quite crucially, Varikas shows that several middle-class women appreciated this equality-in-difference doctrine, developing a form of gender consciousness that drew on it: they took pride in being competent mothers, teachers and philanthropists and sought to increase their social status through such activities. A small segment of middle-class women developed a particular gender consciousness, namely a feminist one, whose relationship to the equality-in-difference notion was far more complicated. Those women stressed "women's" values, reproducing to an extent the roles that the equality-in-difference doctrine assigned to women. Nevertheless, and in contrast to this doctrine, they also emphasised equality rather than difference from men, an equality that was

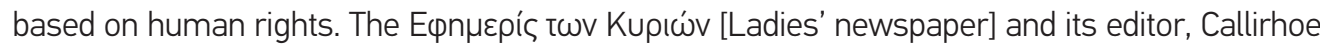
Parren, featured prominently in this first manifestation of feminism in Greece.

Historical research on gender published since the late 1990s has largely built on Varikas' book, while also expanding their scope in several ways. In general, the link between nationalism and the making of middle-class women has been a prominent topic in gender history since the 1980s. ${ }^{49}$ The same applies to the issue of the education of middle-class women. ${ }^{50}$ Moreover, from the 2000s onwards historical works that touch on gender and the middle class have explored sport, often in relation to nationalist visions. ${ }^{51}$

Another area that has been gaining ground is the transnational approach to the history of Greek middle-class women. Notable in this sense is the recent work of Evrydiki Sifneos, Despina Vlami, Psarra, Efi Kanner and Haris Exertzoglou. Sifneos and Vlami form part of an approach to the Greek diaspora that has gained momentum since the 2000s: no longer emphasising the ties of the diaspora with its country of origin, the advocates of this new trend focus on its relationship with the host society ${ }^{52}$ Sifneou and Vlami have probed the merchant diaspora, exploring interconnections between gender and class. Sifneou analyses communities residing in the Sea of Azov. ${ }^{53} \mathrm{Vlami}$ addresses middle-class women of the Greek trading diaspora in the eighteenth and nineteenth centuries, focusing on those based in Livorno.$^{54} \mathrm{It}$ is one of the few works that refers to gender and the middle class in the era prior to 1850 . Vlami does not explore women that were involved in collective action; rather, she analyses the intersection between gender, social class and ethnicity as well as the sociality of those women. ${ }^{55}$

Psarra focuses on a more recent era and studies an issue that has been largely underexplored in relevant scholarship: the ties with the west that Greek feminists developed at the end of the nineteenth and beginning of the twentieth centuries. ${ }^{56}$ The fact that these feminists presented their cause as anchored in Greek nationalism has misled researchers to underscore their connectivity with feminists in other western countries. Psarra explores several types of such transfers, including the circulation of the work of non-Greek feminist works among Greek feminists as well as the face-to-face interaction of Greek and US American as well as French feminists. Such contacts were embedded in the staunch Orientalism that Greek feminists shared at that point and which continued in the first decades of the twentieth century, as Effi Gazi's work also demonstrates. ${ }^{57}$ This feminist Orientalism portrayed the "east" as static and marked by the subordination of women to men; the east was juxtaposed with the west, where Greek feminists believed the potential for women's emancipation lay. 
Kanners' and Exertzoglou's work draws on elements of a transnational perspective that had appeared already in $H E \xi \varepsilon \dot{y \varepsilon} \rho \sigma n \tau \omega v K u \rho ı \omega ́ v$. Varikas had illuminated the contact between subjects in Greece and Greek Orthodox communities in the Ottoman empire, treating this, however, as an extension of a topic of Greek history. By contrast, Kanner and Exertzoglou studied ethnoreligious communities as topics connected with Ottoman history, avoiding, however, an approach that sees the Ottoman empire as a sealed container. They survey in particular the shifting gender representations and practices in the late Ottoman empire as a result of modernisation processes and discourses, which drew, albeit sometimes ambivalently, on the west as a role model. They also consider transfers across the borders of Greece and the Ottoman empire, such as the circulation of the

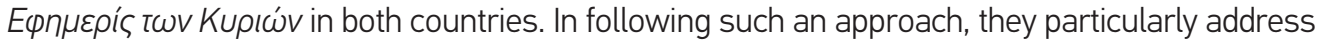
Orthodox middle-class women in the late Ottoman period, exploring their relationship with the Greek state and with Muslims in the empire. Kanner analyses issues such as philanthropy and the discourses on women that circulated in the Orthodox community in Istanbul. ${ }^{58}$ She complements Varikas' work by showing how the equality-in-difference doctrine spread in the Orthodox community of Istanbul. The latter also endorsed a public/private dichotomy: representations of the "public" as a "masculine" realm appeared in the second half of the eighteenth century. Middle-class women were expected to help hellenise the Orthodox millet by making the non-Greek-speaking Orthodox accept the superiority of Greek language and "culture". They were to contribute to this goal mainly through philanthropic activities, which were once again viewed as an extension of their maternal role. Thus, a "feminine" private sphere was considered complementary and, in fact, a pillar for a "hellenised" Orthodox male public sphere. Men who treated women as inferior than men continued to exist, according to Kanner, but were far from hegemonic in that community by the second half of the nineteenth century.

Exertzoglou also addresses the Greek Orthodox communities in the main urban centres of the Ottoman empire, especially in Istanbul and Izmir. ${ }^{59}$ The topic of his research is the reception of the widespread social, cultural and political changes that occurred in the Ottoman empire in the nineteenth century. To examine this, he explores the ways in which the "poor" and "women" served as metaphors through which such change was understood. These metaphors not only allowed the elites of these communities to try to shape behavioural patterns of the "women" and "poor", but also affected the actual practice of those subjects. Similar to Kanner, Exertzoglou addresses the ways in which the Greek Orthodox tried to become hegemonic in the Orthodox millet. He demonstrates that, rather than subscribing to Greek irredentism, they opted for $\varepsilon \lambda$ nvoo $\theta \omega \mu a v i \sigma \mu o ́ s$ or "Graeco-Ottomanism", in an effort to ensure a high level social status in the Ottoman empire rather than contributing to the territorial expansion of the Greek state. Exertzoglou shows, however, that both Greek irredentism, as analysed by Varikas, and Graeco-Ottomanism rested on the same approach to gender relations, which revolved around the equality-in-difference doctrine. What is particularly novel in Exertzoglou's approach is his effort to approach Orthodox and Muslim communities from both a comparative and transnational perspective, developing what could be depicted as an histoire croisée analysis of them. ${ }^{60}$ In studying the formation of the public sphere in the Ottoman empire and its gendered connotations, he shows that the former was not totally fragmented along religious lines. Although the Orthodox endorsed an ardent Orientalism, which construed the east as "feminine", a tendency that had made headway in the west as well, there were still interconnections between them and the Muslims. Moreover, Exertzoglou analyses the shifting gender 
relations among Muslims in the Ottoman urban centres in the nineteenth century, showing that the pattern of the nuclear family gained traction among middle-class Muslims. The latter, similar to the Orthodox middle class, also developed a specific allocation of gender roles.

The other notable development since the 1990s in the analysis of this intersection by gender historians dealing with Greece is that they addressed the shaping of masculinities far more than the study of modern Greece from the perspective of gender had done in the 1980s. A trendsetting publication in this respect was a journal article by Antonis Liakos. ${ }^{61}$ Liakos builds on Connell's approach to hegemonic masculinity, as it appears in Connell's Masculinities ${ }^{62}$ and analyses how their shifting understanding affected the work of Rigas Feraios. He explores the gender connotations of both images and the text in Feraios' work and reaches two conclusions. The first is that the conceptualisation of masculinity, which the ascending middle class in Europe developed in the second half of the eighteenth to the beginning of the nineteenth century, and its link to nationalism, affected Feraios as well. Such conceptualisation prized not only a clear demarcation of gender roles, but also a self-controlled male body as a symbol of the nation as well as the middle-class dominated society. This appeared in Feraios' work in the symbol of Hercules holding a club and was juxtaposed with the purported vagueness of the behaviour of the sultan in terms of gender. The club, a male sexual symbol, would be an emblem of the "Hellenic Republic" that Rigas Feraios aspired to create. The formulation of Greek national visions and middle-class identities rested not only on the signification of femininity, as shown in the works that address the equality-in-difference doctrine, but also of masculinity. Liakos' article was ground-breaking for research on gender internationally: while such research largely argues that emotion was associated with femininity in the nineteenth century, Liakos shows that, at least in Feraios' writings, the proper man had to combine "reason" and "emotion" while dealing with family issues in the context of the "private" sphere. ${ }^{63}$

One more work moving in that direction, but which explores a more recent era, is that of Dimitra Vassiliadou, ${ }^{64}$ who analyses duelling as a core component of middle-class masculinities in Greece from the mid-to-late nineteenth century to the end of the First World War. She shows that such development was not specific to Greece. Drawing on the work of Robert Nye and Ute Frevert, she demonstrates that it resembled what occurred elsewhere in the west at that point. ${ }^{65}$

Another relatively recent study by Yannitsiotis considers the shaping of masculinities in Greece by analysing the making of the middle class in the port city of Piraeus in the last quarter of the nineteenth century. ${ }^{66} \mathrm{He}$ pays particular attention to the interconnected construction of gender and social space. He considers the metaphorical usage of masculinities and femininities, analysing their implications for the making of peiraikotita, namely the local identity in Piraeus.

To sum up, the interest of gender historians in the middle class has been enduring, albeit in shifting ways, from the inception of the field to the present. 


\section{Gender and labour relations}

Another area that gender historians working on Greece began to address in the 1980s was that of labour. In general, historical research on labour relations has intensified in Greece since the late 1980s, but not necessarily from the perspective of gender. ${ }^{67} \mathrm{~A}$ controversial issue among historians dealing with the issue was whether Greece witnessed the formation of a working class. While historians such as Petros Pizanias challenge this, Liakos draws on the work of E. P. Thompson and discerns a process of social class formation, shaped by diverse subjects, such as union members and the state. Liakos claims that work is not just an economic issue, but also a cultural construct. Thus, he has contributed to the swelling chorus of historians who have paid increasing attention to cultural practices since the late 1980s. The gender historians dealing with labour relations have also been an integral part of this tendency: they have highlighted the interconnections in the formation of social class and gender identities, seriously considering the cultural practices through which these identities were formed as well as the agency of the subjects they study. They have also scrutinised gendered hierarchies in diverse workplaces, ranging from factories to homes (in the case of domestic workers).

A main concern for the gender historians who have explored female labour since the 1980s has been the link between professional hierarchies and gender in the public sector. A concomitant topic they have analysed in depth is the feminist reaction to such gendered hierarchies and the feminist collective action to protect women's wage work in the interwar years. Quite significant in this respect is the work of Avdela, who has explored in a number of publications from the late 1980s the women's labour of women beyond the "private" sphere in the early twentieth century. ${ }^{68}$ She argues that the number of women who engaged in such work steadily increased from the beginning of the twentieth century. She demonstrates that women who worked in factories were usually young and their terms of employment did not normally last long. Women who became civil servants were young, albeit somewhat older than those working in industry. Female civil servants usually worked due to necessity, in order to contribute to their family's income as well as to accumulate their dowry. They generally stopped working as soon as they got married. Her work also addresses the issue of women's militancy in the interwar years. She demonstrates that, in contrast to the late nineteenth century, feminism in Greece pivoted around female labour and women's voting rights. ${ }^{69}$ Moreover, she analyses the various strands of feminism that appeared in the period.

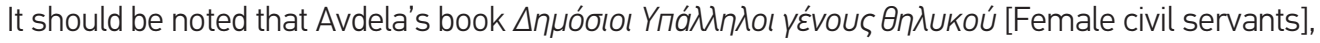
in particular, introduces the systematic study of labour from the perspective of social history in interconnection with an analysis of gender relations, as Leda Papastefanaki pointedly argues. Her use of both quantitative sources, showing the shifting number of female civil servants, but also of qualitative ones, which shed light on their experiences, testifies to this. ${ }^{70}$

Since the 1990s, and especially since the 2000s, the analysis of labour in from the perspective of gender has intensified. The works of Kostas Fountanopoulos and Papastefanaki are noteworthy in this respect: In particular, the former examines the making of working-class cultures and militancy in Thessaloniki in the early twentieth century. ${ }^{71}$ Although gender is not the main focus of his research, it constitutes one of the factors that he examines. In his analysis of patterns of female labour, he makes a compelling point that women were not necessarily employed as unskilled la- 
bour. He critically reflects on relevant statistics, asserting that they should not be taken at face value, since tended to label female work as "unskilled", even if it required complex skills. Moreover, in contrast to Avdela, he argues that the labour market integration of women should not be conceptualised as an extension of the "private sphere" roles allocated to them by the hegemonic discourse on gender. While Fountanopoulos maintains that this explains the positions assigned to them in the tertiary sector, such as in the field of education, it does not furnish an adequate explanatory package for the job positions offered to women in the secondary sector, such as in machine shops, already in the early twentieth century.

Papastefanaki places the exploration of the allocation of gender roles at the workplace at the forefront of her analysis in her study of the Retsina textile industrial complex in Piraeus. ${ }^{72}$ Drawing on the research of Joan Scott, ${ }^{73}$ Papastefanaki argues that the examination of gender is not meant merely to add more information to the study of other topics, but, rather, to help fundamentally reconsider their historical analysis by highlighting the (re)making and legitimisation of gendered hierarchies in structuring social interaction in general. She also echoes the arguments put forth by Sonya Rose, namely that the study of industrial relations should consider not only economy, but also culture; and that gender was key to the shaping of such relations. ${ }^{74}$ In this vein, Papastefanaki shows that there was a very clear and gendered allocation of roles in the industrial complex she explores. She proves that this allocation was linked to power relations not only between different social classes, but also within the same class. In particular, and similar to Fountanopoulos, she demonstrates that male workers earned higher wages than their female colleagues for the same work. She adds that almost exclusively men progressed towards the higher ranks of the industry's hierarchy. Again, similar to Fountanopoulos, she shows that, even if the tasks assigned to women required intellectual skills, they were quite frequently labelled as "unskilled" labour, which, as she also notes, was reflected in the relevant statistics. A particularly novel element of her work is her argument that women did not necessarily work for short periods. By contrast, she discerns two types of employment: one containing skilled male and female workers, both skilled and unskilled, who worked for long periods (over 10-15 years); and one including mainly women working at irregular intervals and who usually withdrew from work upon marriage. According to data she presents from about 16 textile industries in Piraeus, around 30\% of women worked longer than 10-15 years. In so doing, she critically approaches several sources, such as official statistics and population censuses, which underestimated the participation of women in the workforce. ${ }^{75}$ She complements such material by extensively using documents from businesses archives that record their female employees in more detail. In carefully elaborating on these issues by concentrating on the Retsina complex, she avoids a methodologically nationalist approach: she compares the allocation of gender roles there with the situation not only elsewhere in Greece, but also in the US and UK.

The examination of female labour by gender historians since the 1980s has focused on industrial workers. Still, the recent work of Pothiti Hantzaroula is an exception to this trend, as she explores domestic workers in Greece in the first half of the twentieth century. This was the topic of her PhD research as well as of a monograph and several articles. ${ }^{76}$ Hantzaroula was correct to note that historians who dealt with the working class in Greece, such as Pizanias, tended to exclude from the scope of their analysis forms of labour that did not manifest themselves in the "public" sphere. In addressing domestic work, Hantzaroula probes the ways in which these female workers were 
shaped as subordinate subjects in terms of social class and gender. In doing so, she introduces the study of emotions to the field of gender history in modern Greek historiography. In terms of sources, her work carefully analyses oral testimonies. Hantzaroula takes an interdisciplinary approach to oral history, drawing on the work of anthropologist and oral historian Riki van Boeschoten as well as of historian Luisa Passerini, who was also her PhD supervisor at the European University Institute in Florence. In using oral testimonies, Hantzaroula does not expect them to simply reflect the actual experience of those workers. Rather, they indicate how the interviewees made sense of such experience in forging their class and gender identities. She discerns three types of female domestic workers as regards their attitude towards domestic labour: those who came from the Cycladic islands treated domestic labour as a means of accumulating money for their dowry. For female refugees from Anatolia, it served as a means of survival; they often engaged in domestic and industrial work interchangeably. Finally, for women from continental Greece it functioned as a means of adoption by the family for whom they worked. ${ }^{77}$

In the last two decades, the transnationalisation apparent in the study of middle-class women from the perspective of gender has also emerged in the study of female labour. This is evident in those studies of migration that also address gender. The work of Lina Venturas is particularly noteworthy in this respect. ${ }^{78}$ She stresses that until the mid-1970s women tended to be sidelined in relevant research, since their mobility was considered a secondary phenomenon, dependent on the movement of men. From that point, relevant scholarship has increasingly challenged this assumption, shedding light, for instance, on mutual aid networks established by women in the diaspora. She also concurs with those scholars criticising the simplistic argument that migration was a quintessentially emancipating experience for female migrants. Indeed, Venturas argues that female migrants escaped from the restrictive honour codes of their natal areas; some of the women who migrated had breached those rules. Nevertheless, research should consider several factors, such as their education, the existence of mutual aid networks in the host societies and the reasons why these women were forced to or decided to migrate, to illuminate whether migration contributed to female emancipation or subordination. In any case, there is no one-size-fits-all answer to this question. Ioanna Laliotou's work on migration and cultures of transnationalism between the US and Greece also addresses the intersection of social class, race and gender in the making of migrants' subjectivity. She highlights, for instance, the ways in which labour was formulated as a gender-specific concept in representations circulating among migrants. ${ }^{79}$ Despite the fact that gender has been increasingly the subject of analysis in the west in relation to race, as mentioned in the second section of this article, this development has largely failed to affect gender as approached in modern Greek historiography. Laliotou's work is one of the few exceptions.

Finally, the study of labour by gender historians from the 2000s on has also taken the making of masculinities more seriously into consideration. Dimitra Lambropoulou has meticulously scrutinised the making of class and gender identities of construction workers in Athens from 1950 to 1967..$^{80}$ Her work clearly shows that social class and gender are mutually constitutive. She explores their homosociality to prove that it reproduced hierarchical relations. In this vein, she demonstrates how the master substituted the role of the parents for young apprentices. The latter were regarded in the context of such homosociality not only as lacking job-related skills, but also as imperfect men; only by becoming competent construction workers, relying on themselves and not needing 
the guidelines of the master, would they be able to overcome this state of "imperfection". The male homosociality of construction workers was also conducive to intimacy and solidarity, however, which developed particularly in the social space of the piazza, namely cafés in the centre of Athens where those workers gathered, awaiting work. Such solidarity, according to Lambropoulou, underpinned the intense political activity of construction workers in Athens. It is noteworthy that her work has also influenced anthropologists of gender: in analysing male homosociality in Athens, Kostas Yannakopoulos cites her work when stressing the development of queer performance by some men who gathered in the piazzas. ${ }^{81}$

Therefore, not only have gender historians working on labour refrained from equating the "public" with men and the "private" with women, but they have also uncovered the diverse ways in which femininities and masculinities are shaped and performed in various contexts.

\section{Beyond the middle-class and labour relations}

The article has thus far analysed the shifting approaches of gender historians to the analysis of the middle class and labour, topics that have figured prominently in their analyses. Still, the scope of their research has broadened since the 2000s, a process that this section turns.

In this respect, modern Greek historiography has slowly begun to study the shaping of heteronormativity as well as exceptions to it: quite tellingly, the very promising ongoing research of Despo Kritsotaki scrutinises the emergence and development of discourses on intersex people in Greece. It shows that during the nineteenth century, similarly to what occurred elsewhere in the west, medical discourses treated such people as morally and socially deviant. In the second half of the twentieth century, medicine moved further in the west in general and in Greece in particular, proposing medical interventions to eliminate the intersex condition. ${ }^{82}$ However, historical research on Greece beyond heterosexual men and women has been limited; relevant analyses have been mainly pursued by anthropologists, especially Yannakopoulos, Kantsa and Elisabeth Kirtsoglou. ${ }^{83}$

The study of gender has also expanded in terms of the topics it considers. In addressing militancy in relation to the position of women in Greek society, relevant historiography had concentrated on communist, socialist and liberal organisations. However, historians have growingly begun to probe the discourse of conservative organisations on gender. This is manifest in the examination of conservative responses to youth cultures, which are addressed later in this section. It is also scruti-

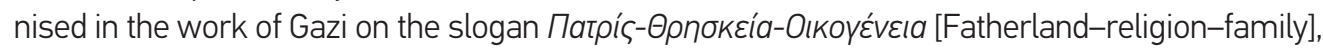
which explores the emergence of this slogan from 1880 to $1930^{84}$ while analysing the gendered connotations of and the debates surrounding it. In this vein, she highlights the reaction of school advisors to the ways in which Rosa Imvrioti taught history at Marasleio Pedagogical Academy. They mounted a loud critique of her teaching, which was linked not so much to her Marxist orientation, but, rather, to the fact that she was a woman. They echoed militaristic stereotypes, which were spreading elsewhere in Europe, such as in fascist Italy, which believed that teaching history was expected to instil a "masculine ethos" in pupils, something a woman was incapable of trans- 
mitting. Besides this topic, gender historians have also examined rightwing approaches to gender during and after the Greek Civil War, especially in the treatment of those women that were affiliated with the left. ${ }^{85}$

Although a comprehensive history of consumption in Greece and its link to gender relations has yet to appear, the perspective of gender has begun to work its way into the topic of mass consumption. Although the latter has hitherto been underexamined, Achilleas Hadjikyriacou's monograph has illuminated the ways in which masculinity was portrayed in relation to consumption in Greek popular cinema from 1949 to 1967. He has also probed the reception of these movies in a broad range of newspapers and magazines. ${ }^{86}$ Panagiotis Zestanakis has scrutinised the link between masculinity and consumption in the magazine Klik in the late 1980s, showing how it tracked and helped shape a pleasure-oriented masculinity that gained momentum in the middle class. ${ }^{87} \mathrm{He}$ has also examined the representations and practices of female car drivers and motorbike riders in Athens in the same decade ${ }^{88}$ At that point, a growing number of women engaged in these activities, although they were still numerically fewer than male car drivers and motorbike riders. Both Zestanakis' and Hadjikyriacou's research draws on Connell's conceptual framework with regard to masculinities and rides on the wave of the growing interest in masculinities that gender historians working on Greece have evinced since the 2000s. Zestanakis' work on female car drivers and motorbike riders is also linked to a novel tendency among scholars dealing with gender in Greece to seriously consider the spatial turn, which examines the multiple and shifting meanings assigned to space and their complex link to human activities. ${ }^{89}$

Another topic that was first approached from the perspective of gender at that point was that of warfare. Poulos has explored the relationship between women, on the one hand, and the preparation and the experience of war, on the other, in the nineteenth and twentieth centuries in a monograph..$^{90}$

In terms of thematic expansion, another tendency in the gender history of Greece is the effort to consider the practices of the numerous women that lived beyond the main urban centres. Noteworthy in this respect is Avdela's monograph on violence and honour codes after the Civil War. ${ }^{91}$ Her book is based on a wide range of sources, including trial transcripts and press coverage of honour-related incidents of violence, covering both urban and rural areas. She does not aim to offer quantitative data concerning where such incidents occurred. However, Avdela shows that they were widespread almost throughout Greece and not confined to specific areas, such as Mani and Crete, as it is widely held. She also demonstrates that the use of violence became increasingly delegitimised in the 1960s as a means of defending honour: while an increasing number of incidents described as "honour crimes" were recorded in the 1950s, fewer cases were reported in the following decade before almost disappearing prior to the establishment of the dictatorship in 1967. In doing so, Avdela complements the work of several anthropologists who have probed honour codes in Greece and whose work on the Greek countryside, as Yannitsiotis aptly remarks, has largely been neglected by historians. ${ }^{92}$ The novelty of her work also lies in the analysis of honour as an "emotional regime", ${ }^{93}$ which builds on a concept introduced by anthropologist William Reddy. Alongside the work of Hantzaroula, this monograph demonstrates the growing interest of gender historians in emotions. 
Evdoxios Doxiadis also includes provincial towns and in rural areas in his work that explores the links between women, law and property during the transition from the Ottoman empire to the Greek state (1750-1850). ${ }^{94}$ He shows the ambiguous impact of this transition on women's rights with regard to property. Although their relevant rights were formally codified and recognised by the Greek state, several developments, such as the emergence of a modern judicial system that excluded women, "allowed men almost total control over their wives' properties". ${ }^{95}$ Still, despite the publication of those works by Avdela and Doxiadis, which deal to a greater or lesser extent with rural areas, gender relations in the latter remain underexamined.

The growing weight assigned to intersections beyond gender and social class is another way in which the scope of gender history research has expanded since the 2000s. In this vein, several historical works have addressed the relationship between gender and age. Although a few such works had appeared already in the mid-1980s, they almost exclusively addressed girls in the 19th and the very beginning of the 20th century. ${ }^{96}$ From the 2000 s on, such research has expanded to masculinities in relation to class and age. ${ }^{97}$ It has also growingly probed the interwar period as well as in the 1960s and 1970s. Relevant historical research revolves around gender relations in the National Youth Organisation (EON), the official youth organisation established by the authoritarian Metaxas regime that ruled from 1936 to 1941. Nevertheless, according to Rosa Vasilaki, the EON paved a "bizarre path to emancipation" for women despite the aims of the regime that established it and confined women to the "private" sphere..$^{98}$ Female EON members had the opportunity to develop networks beyond the supervision of their parents through their participation. This was a watershed that enabled them to develop skills and undertake responsibilities that many of them found useful in the early 1940s, when taking part in the leftwing resistance against the tripartite occupation of Greece. By contrast, Odette Varon-Vassard, who has authored a monograph on leftwing youth resistance groups during the occupation and dedicates a section to their female members, finds no linear trajectory between the membership of the EON and resistance groups. The former was quintessentially the tool of an authoritarian regime and imposed a similar pedagogy, which was fundamentally different from the militant activity in the framework of resistance in the early 1940s.9

Work on youth and gender during the 1960s and 1970s in Greece has probed both the discourse on youth and the experience of those partaking in youth culture. Avdela's work has been groundbreaking in this respect as well. She shows that the spread of novel forms of youth leisure from the 1950s, emanating from elsewhere in the west and, especially, the USA, caused rancorous debates around whether and to what extent they jeopardised dominant gender norms: a wide array of social and political subjects, both on the right and the left, claimed that these flows made girls repudiate the "advantages of purity" and rendered boys violent. ${ }^{100}$ In doing so, Avdela appropriates a notion introduced by Passerini, namely that youth serves as a metaphor for social change. ${ }^{101}$ In a recently published work, Avdela examines the Greek juvenile justice system in the 1950s and 1960s and the gendered approach towards sexuality in its treatment of young people of differing gender. ${ }^{102}$ It was common for young women to be subjected to chastity tests, regardless of their specific accusation. Those who were found to have engaged in sex were regarded as immoral in general. By contrast, the same system regarded sexual relationships as a "normal" element of the behaviour of young men. The book also highlights that young heterosexual men often engaged in same-sex practices without developing a gay identity: it was a rite of passage to a sexually active life. In demonstrating 
this tendency, she incorporates the argument put forth by Yannakopoulos that heterosexual male desire in Greece has frequently adopted same-sex sexual practices. ${ }^{103}$ It is noteworthy that Avdela's book is one of the very few historical works on gender that deal with same-sex sexual practices.

The interweavings of gender and age in the 1960s also appear in a number of works by Kostas Katsapis. One addresses the emergence of youth culture in Greece by focusing on the reception of rock ' $n$ ' roll as well as the reaction of a wide array of social and political subjects towards it. ${ }^{104}$ The second focuses on conservative reactions against youth culture. ${ }^{105}$ While his work does not concentrate on gender, this factor is addressed in his analysis. Resonating with Avdela, he shows that the fear of the potentially "harmful" impact of novel leisure practices on the making of masculinities and femininities figured prominently in the critiques of rock ' $n$ ' roll.

In his work on politics and everyday life in the junta period (1967-1974), Kostis Kornetis also deals with youth in relation to gender. ${ }^{106} \mathrm{His}$ relevant research in based on both written and oral sources. In dealing with the latter, Kornetis follows a similar approach to Hantzaroula: he does not seek factual validity in them but, rather, insights into how the interviewees construed their experience. In so doing, Kornetis considers how events that transpired between the narrated era and the time of the interview may have also affected the memory of his interviewees. This approach heavily draws on the conceptual framework of his $\mathrm{PhD}$ supervisor, Passerini. In terms of periodisation, resonating with historian Arthur Marwick, Kornetis argues that Greece also experienced substantial cultural and social transformations in the era of the "long 1960s", which, according to Marwick, lasted approximately from 1958 to $1974 . .^{107}$ In this context, the number of university students increased and so too did the ratio of female to male enrolment. Kornetis shows that women played an important role in clandestine groups that opposed the dictatorship and became growingly emancipated in everyday life: for instance, they developed a "more uninhibited attitude toward [heterosexual] sexuality" before marriage. ${ }^{108}$ However, considering the varying impact of "long 1960s" developments on people of differing gender, Kornetis shows that such emancipation did not lead to full equality between heterosexual women and men in the antidictatorship groups.

My own work probes leftwing youth politics, leisure and sexuality in the following years, namely from 1974 to $1981 .{ }^{109}$ I analyse the symbolic representations of specific political performances and their links to gender, showing, for instance, that eloquence in assemblies was associated by the groups in question with heterosexual masculinity. I also argue that the experience of young leftwingers in post-1974 Greece, including their political activities, leisure pursuits and sexual practices, was a plural phenomenon, which varied according to gender and social class: in this vein, the transition to democracy constituted an era of opportunity and constraint for (young) people of differing gender. Drawing on Kevin Murphy and Jennifer Spear, I show the complex ways in which sexuality and gender were entangled and mutually constitutive in the rhetoric and experience of the leftwingers under study. ${ }^{110}$ Some groups, such as the pro-Soviet Communist Youth (KNE), endorsed a normative rhetoric, lauding the stable heterosexual couple and, thus, lambasting performances of masculinity and femininity that strayed from this. Still, premarital sexual relationships, often ephemeral, continued to be a common practice among young leftwingers of all stripes after the restoration of democracy. While, however, multiple ephemeral relationships were a source of pride for heterosexual young male leftwingers, they impeded the progress of women towards the higher ranks of such 
organisations. Thus, I stress that the gender perspective helps us develop a nuanced analysis of the relationship between the restoration of democracy and the liberalisation/pluralisation of lifestyles. I also indicate the shifting meanings attached to femininities and masculinities within leftwing youth groups, especially due to the emergence of the women's and the homosexual liberation movement. In contrast to other western countries, these movements appeared in Greece not in the late 1960s, but after the collapse of the dictatorship and, especially, from the late 1970s to mid-1980s. The relationship between feminism/homosexual liberation and the left was strained, ranging from hostility in the case of pro-Soviet communists to cautious openness among the Eurocommunists. ${ }^{111} \mathrm{Nev}$ ertheless, echoing Connell, who argues that masculinities are dynamic and affected by the making of femininities as well, I show that the women's liberation movement affected not only female but also some male leftwingers. Feminism made those male leftwingers reflect on the formulation of a non-sexist male behaviour as well as criticise the strict discipline on gender and sexual mores promoted by pro-Soviet and some Maoist groups. Thus, what appeared was an entanglement between the reconfiguration of collective action patterns and gender. Such an interconnection was not unique to Greece, but common across Europe at that point in the 1970s. ${ }^{112}$

While gender historians have increasingly included youth in their research, often comparing the Greek case to elsewhere in the west, less has been written on gender relations among elderly people. Thus, considerable ground remains to be covered in the intersection of gender and age in the gender history of Greece.

\section{Conclusions}

This article analyses the emergence and development of gender in modern Greek historiography, exploring works that incorporate, even to an extent, the gender factor. It shows that, although historical works on women were being authored even in the nineteenth century, the systematic analysis of gender practices and representations began in the 1980s in the context of the women's liberation movement. Gender history, however, was largely marginalised in Greek academic institutions, a factor that is also linked to its ambiguous relationship with the rise to prominence of "new history" paradigm. After an era of stagnation in the 1990s due to lack of funding and institutional support, gender history has been gaining momentum and has been increasingly incorporated into Greek academia. This development is related to new programmes dealing with gender that have been established in Greek universities as well as the creation of the Greek National Committee of the International Federation for Research in Women's History. In this vein, since the late 1990s there has been a process of diffusion of the study of gender, as Fournaraki and Yannitsiotis argue: even some historians whose research does not concentrate on gender tend to take this into account. As a result, it is becoming more challenging to refer to "gender history" as a distinct field. Still, this does not mean that all strands of modern Greek historiography have been influenced by reflection on gender: diplomatic and military history are two remarkable exceptions. Thus, this diffusion has been limited.

Similar to what Papataxiarchis and Kantsa have argued regarding the study of gender at the international level, modern Greek historiography witnessed no linear transition from the study of wom- 
en to the exploration of gender, or - to challenge Morgan's argument - from a history of subjects to a history of relations. Works dealing with gender in modern Greece initially focused on the history of women as subjects of history, evincing, simultaneously, a clear interest in gender relations; they explored how the construction of gender difference was linked to values associated with social class as well as with shifting notions of citizenship. The topics that initially featured prominently in this historiographical strand, as Avdela has aptly remarked, were women's militancy from the late nineteenth century to the 1940s, the practice of middle-class women as well as female labour. At that point, "new history", whose main concern was to scrutinise economic structures that led to Greece's purported Greece's path to modernity, was gaining momentum in Greek academia. Historical research on gender critically reflected and helped revise such work by addressing social class issues from the perspective of social and cultural history, in an approach that did not present the "economic" sphere as determining the "social".

The interest in the middle and working class has continued to figure prominently in modern Greek historiography dealing with gender since the late 1990s, as does the effort to probe the shifting understandings of gender difference and their implications for the understanding of social and political conditions in general. Nevertheless, in both cases relevant analyses are marked by what I would label as a growing transnationalisation in their scope. One more development that this article has demonstrated is the growing expansion of gender-related themes being explored: while the concern for the history of women as subjects of history has not evaporated, this expansion includes a growing interest among gender historians in masculinity, but also two tendencies that have not been addressed in previous accounts of gender. Since the 2000s such analyses have considered in more detail the intersection of gender not only with social class, but also with age, focusing on youth. They have also begun to consider gender relations among people who live in non-urban centres, although the relevant topic remains underexamined.

Such enrichment should be attributed to the fact that gender historians working on Greece have been receptive to an extent of developments in research on gender mainly in the UK, US, France and in the European University Institute in Florence. This enrichment should be also linked to their engagement, especially in the last two decades, in interdisciplinary dialogue, particularly with so$\mathrm{cial} /$ cultural anthropologists, by whom they have been influenced but whom they have also affected. The anthropologists have also been quite open to shifting approaches to gender in the academia worldwide, especially in the west.

There are developments in gender history and theory internationally, however, to which gender historians, both in Greek academia and in other academic environments, have not been particularly receptive: Quite tellingly, queer theory has largely failed to make an impact. Issues such as the formation of homosexuality in relation to the making of heterosexuality as well the shifting meanings attached to them have received little attention from gender historians working on Greece. They will hopefully be able to secure the financial and institutional support that will enable them to continue to engage in a transdisciplinary and transnational dialogue. However, it remains a possibility that the ensuing crisis will jeopardise developments in this regard, preventing the "small wallflower" from further blossoming. 


\section{NOTES}

1 Rüdiger Hachtmann, "Tourismusgeschichte: ein Mauerblümchen mit Zukunft! Ein Forschungsüberblick," in H-Soz-u-Kult, 6 Oct. 2011, accessed 11 Nov. 2016, http://hsozkult.geschichte.hu-berlin.de/ forum/2011-10-001.

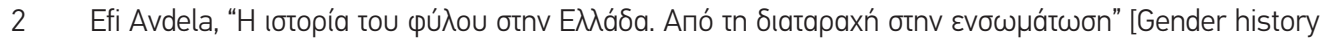

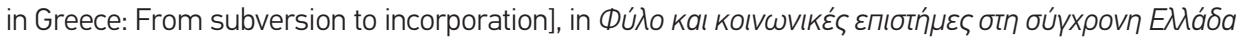
[Gender and social sciences in contemporary Greece], ed. Venetia Kantsa, Vasiliki Moutafi and Evthymios Papataxiarchis, 89-117 (Athens: Alexandria, 2010); Eleni Fournaraki and Yannis Yannitsiotis, "Three decades of women's and gender history in Greece: an account," Aspasia 7 (2013): 162-73.

3 Avdela, "H ıøтopía tou pú̉ou," 104.

$4 \quad$ Ibid., 103.

5 Ibid.

6 For an overview of such works, see Angelika Psarra and Martha Michailidou, "'Few women have a history': Callirhoe Parren and the beginnings of women's history in Greece," Gender \& History 18/2 (2006): 400-411.

7 See, for instance, Nikolaos Papadogiannis, "Red and purple? The impact of second-wave feminism on young Greek eurocommunists in the 1970s," European Review of History 22/1 (2015): 101-19.

8 For instance, Efi Avdela, "Rapports salariaux et division sexuelle du travail: les femmes fonctionnaires dans la première moitié du 20e siècle en Grèce" (PhD diss., Université Paris 7-Jussieu, 1989), which was supervised by Michelle Perrot, a specialist in women's and gender history.

9 Dimitra Lambropoulou, Antonis Liakos and Yannis Yannitsiotis, "Work and gender in Greek historiography during the last three decades," in Professions and Social Identity: New European Historical Research on Work, Gender and society, ed. Berteke Waaldijk (Pisa: Pisa University Press, 2006), 2-4; Yannis Yannitsiotis, "Social history in Greece: new perspectives," East Central Europe / L'europe Du Centre-Est 3435/1-2 (2008): 104-7.

10 About relevant works, see, for instance Nicos P. Mouzelis, Politics in the Semi-Periphery (London: Mac-

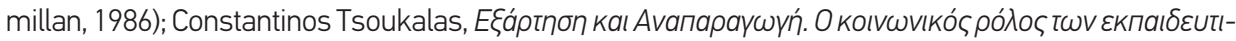

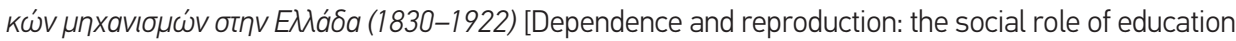

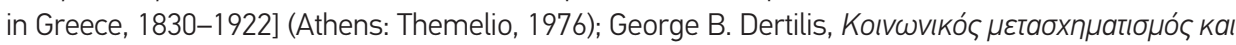

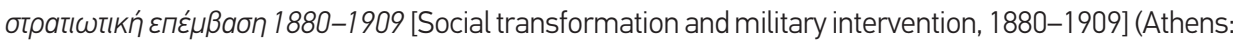
Exantas, 1977).

11 In emphasising clientelism as a means of analysing politics and social relations in Greece, scholars have been greatly influenced by the work of John Petropoulos, especially his Politics and statecraft in the kingdom of Greece, 1833-1843 (Princeton: Princeton University Press, 1968). The book was translated into Greek in 1986, but, according to Liakos, it had already influenced historians and political scientists.

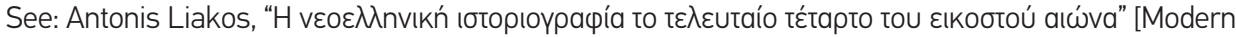
Greek historiography in the last quarter of the 20th century], Synchrona Themata 76-77 (2001): 80. See also Antonis Liakos, "Modern Greek historiography (1974-2000). The era of tradition from dictatorship to democracy," in (Re)Writing history: historiography in southeast europe after socialism, ed. Ulf Brunbauer, 351-78 (Münster, LIT Verlag, 2004).

12 Lambropoulou, Liakos and Yannitsiotis, "Work and gender," 2-4.

13 ibid., 2-4. 


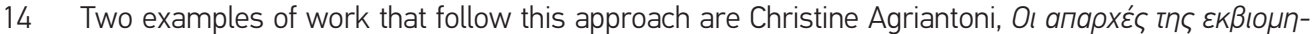

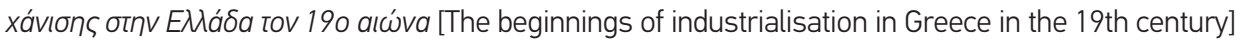

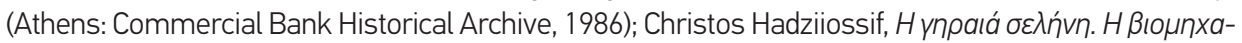
vía oinv EMáda 1830-1940 [The old moon: industry in Greece, 1830-1940] (Athens: Themelio, 1993). For more on "new history", see Liakos, "Modern Greek historiography."

15 Yannitsiotis, "Social history," 108.

16 Avdela, "H ıøtopía tou pú̉ou," 94.

17 Ibid., 93-94.

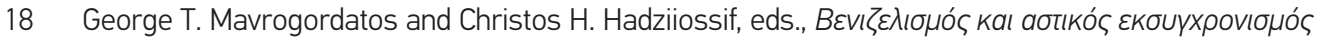
[Venizelism and bourgeois modernisation], Irakio: Crete University Press, 1992

19 Avdela, "H ıøтopía tou pú̉ou," 94.

20 Fournaraki and Yannitsiotis, "Three decades," 163.

21 Ibid., 164

22 Avdela, "H ıøтopía tou qúरou," 105.

23 Fournaraki and Yannitsiotis, "Three decades," 163.

24 See, for instance, the special forum of Diplomatic History 36/4 (2012), entitled "Gender and sexuality in American foreign relations".

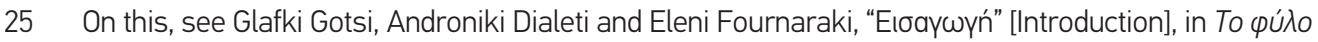

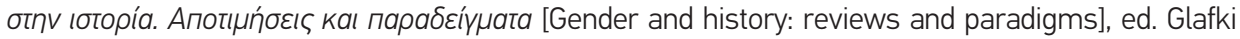
Gotsi, Androniki Dialeti, Eleni Fournaraki (Athens: Asini, 2015), 52.

26 Georg G. Iggers, "Reflections on the historiography of the twentieth century from the perspective of the twenty-first century," in Historein 16/1-2 (2017): 149-158.

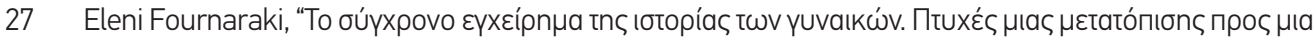

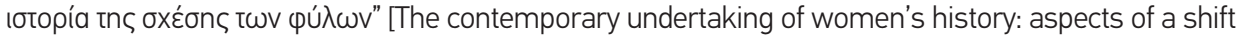
towards a history of gender relations], Mnimon 19 (1997): 187-90.

28 For instance, see Nancy Cott, The Bonds of Womanhood: Woman's Sphere in New England, 1780-1835 (New Haven: Yale University Press, 1977). On an overview of the separate spheres approach and its

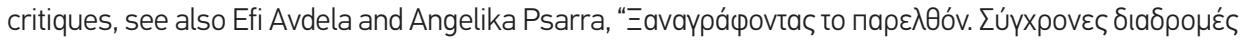

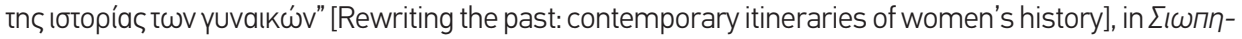

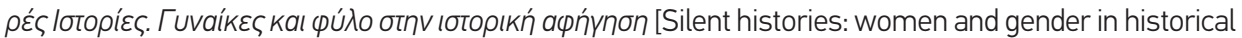
narration], ed. Efi Avdela and Angelika Psarra (Athens: Alexandria, 1997), 31-33.

29 On this issue, see Sue Morgan, "Introduction: writing feminist history: theoretical debates and critical practices," in The feminist history reader, ed. Sue Morgan (New York: Routledge, 2006), 8.

30 Fournaraki, “To oúyxpovo," 198.

31 Joan Wallach Scott, "Gender: a useful category of historical analysis," American Historical Review 91/5 (1986): 1053-75.

32 Judith Butler, Gender trouble: feminism and the subversion of identity (New York: Routledge, 1990).

33 R. W. Connell and James W. Messerschmidt, "Hegemonic masculinity: rethinking the concept," Gender and Society 19/6 (2005): 829-59. 
34 Ibid.

35 See, for instance, Michael Roper and John Tosh, eds., Manful assertions: masculinities in Britain since 1800 (London: Routledge, 1991).

36 Morgan, "Introduction," 19.

37 Martha Vicinus, Intimate friends: women who loved women, 1778-1928 (Chicago: University of Chicago Press, 2004).

38 Ibid., xxii-xxiii.

39 Morgan, "Introduction," 22.

40 Jeanne Boydston, “Gender as a question of historical analysis," Gender \& History 20/3 (2008): 559, 564, 569,578 . Another article employing a similar argument that the study of gender should critically approach binary systems of signification, which gender historiography has largely failed to do in practice, according to the author, is Anna Krylova, "Gender Binary and the Limits of Poststructuralist Method," Gender \& History 28/2 (2016): 307-23. It should be noted that both Boydston and Krylova are in favour of reconfiguring the way in which gender is used as a concept by historians rather than discarding it.

41 Gisela Bock, "Women's history and gender history: aspects of an international debate," Gender \& History 1/1 (1989): 7-30.

42 Boydston, “Gender as a question," 563. On Scott's relevant point, see "Gender: a useful category," 1069.

43 About the factors causing the oppression of Third World women, see, for instance, the following work of the Africanist Cheryl Johnson-Odim, "Common themes, different contexts: third world women and feminism," in Third world women and the politics of feminism, ed. Chandra Talpade Mohanty, Ann Russo and Lourdes Torres, 314-27 (Bloomington: Indiana University Press, 1991.

44 Morgan, "Introduction," 11.

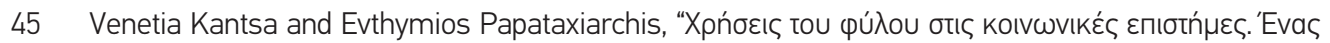

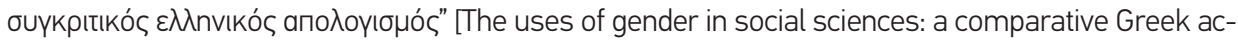

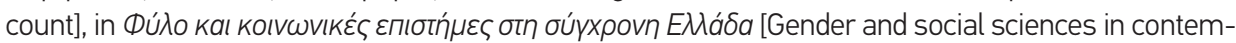
porary Greece], ed. Venetia Kantsa, Vasiliki Moutafi and Evthymios Papataxiarchis (Athens: Alexandria, 2010), 6-7.

46 Ibid., 1-50.

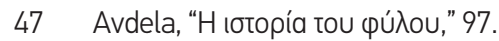

48 Gender history in general has challenged such a perspective, offering a broader understanding of politics. For this remark, see Avdela, "H ıбторía tou pú̉ou," 99-100. About women's militancy in general in

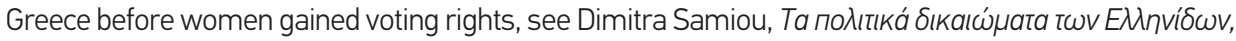
1864-1952 [The political rights of women in Greece, 1864-1952] (Athens: P. N. Sakkoulas, 2013).

49 For a recent relevant work, see Demetra Tzanaki, Women and nationalism in the making of modern Greece: the founding of the kingdom to the Greco-Turkish war (London: Palgrave Macmillan, 2009).

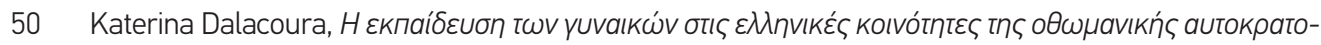

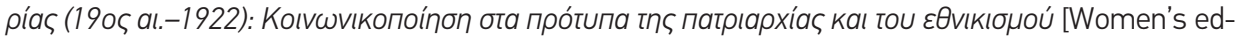
ucation in the Greek communities of the Ottoman empire: women's socialisation, patriarchy and na-

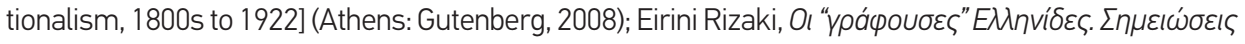

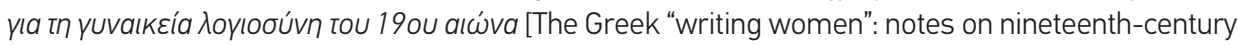

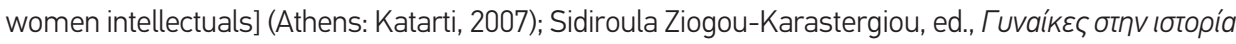




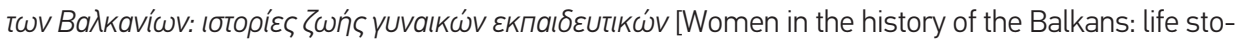
ries of women teachers] (Thessaloniki: Vanias, 2010).

51 Christina Koulouri, Sport et société bourgeoise: Les associations sportives en Grèce 1870-1922 [Sport and bourgeois society: the sport associations in Greece, 1870-1922)] (Paris: L'Harmattan, 2000); Yannis Yannitsiotis, "Urban space and national self-presentation," in Christina Koulouri, ed., Athens, Olympic city 1896-1906 (Athens: International Olympic Academy, 2004), 237-94; Eleni Fournaraki, "Bodies that differ: mid- and upper-class women and the quest for 'Greekness' in female bodily culture (1896-1940)," in Sport, bodily culture and classical antiquity in modern Greece, ed. Eleni Fournaraki

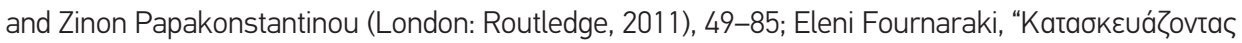

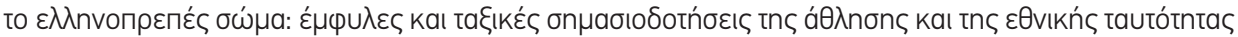

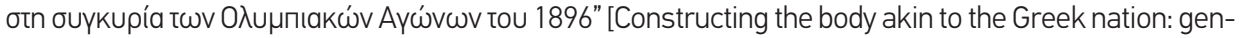
der and social class in the signification of sport and national identity in the context of the 1896 Olympic

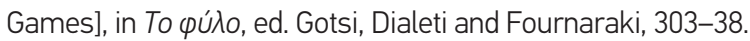

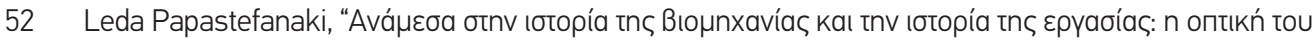

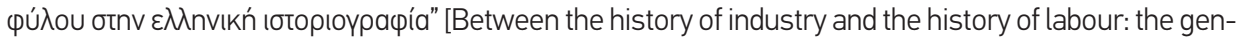

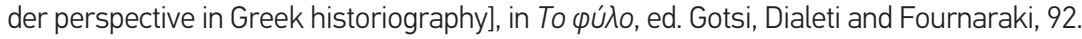

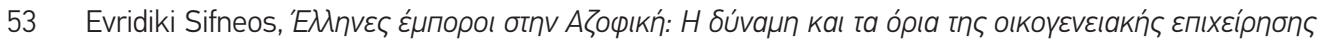
[Greek merchants in the Azov sea: the power and the limits of a family enterprise] (Athens: National Hellenic Research Foundation/Institute of Neohellenic Research, 2009).

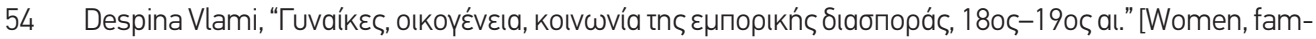
ily, society of the merchant diaspora, 1700s-1800s], Ta Istorika 45 (2006): 243-80.

55 The aforementioned contributions by Sifneos and Vlami are novel not only due to their transnational perspective but also because they are among the few works on gender history of Greece that address the "family" as an autonomous research field, as Dimitra Vassiliadou aptly remarks. See Dimitra Vassi-

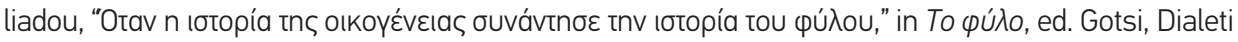
and Fournaraki, 204.

56 Angelika Psarra, "A gift from the new world: Greek feminists between east and west (1880-1930)," in Ways to modernity in Greece and Turkey: Encounters with Europe, 1850-1950, ed. Anna Frangoudaki and Caglar Keyder (London: IB Tauris, 2007), 150-75.

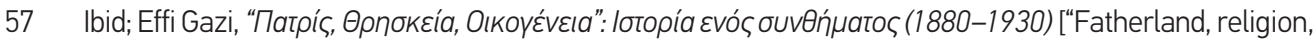
family": history of a slogan, 1880-1930] (Athens: Polis, 2011, 210).

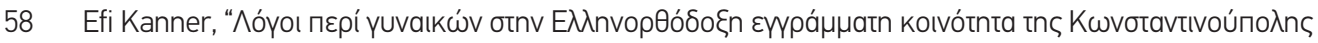
(1856-1908)" [Discourses on women in the Greek Orthodox literate community in Constantinople, 1856-1908], Ta Istorika 35 (2001): 299-334.

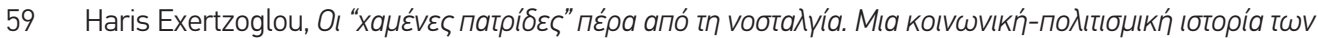

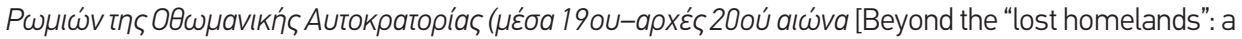
socio-cultural history of the Rum in the Ottoman empire, mid-19th-early 20th centuries] (Athens: Nefeli, 2010).

60 On histoire croisée, see Michael Werner and Bénédicte Zimmermann, "Beyond comparison: histoire croisée and the challenge of reflexivity," History and Theory 45 (2006): 30-50.

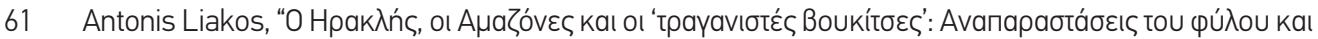

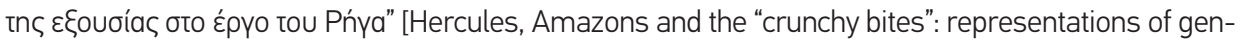
der and power in Rigas' work], Minmon 23 (2001): 99-112. 
62 R. W. Connell, Masculinities (Cambridge: Polity, 1996).

63 About the disassociation of masculinity from emotion in the west since the Enlightenment, an assumption that Liakos contests, see Victor Seidler, Rediscovering masculinity: reason, language and sexuality (London: Routledge, 1989).

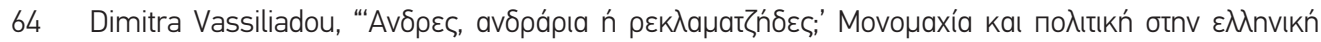

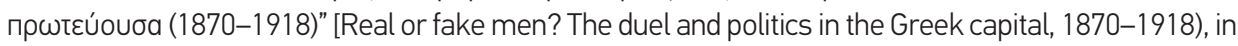

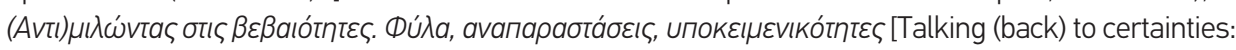
gender, representations, subjectivities], ed. Dimitra Vassiliadou, Panagiotis Zestanakis, Maria Kefala and Maria Preka (Athens: Group for the Study of History and Society (OMIK), 2013), 85-112.

65 She especially draws on Robert A. Nye, "Honor codes in modern France: a historical anthropology," Ethnologia Europaea 21 (1991): 5-19; Ute Frevert, "Male crime in nineteenth-century Germany: duelling," in Gender and crime in modern Europe, ed. Margaret Arnot and Cornelie Usborne (London: Routledge, 1999), 173-88.

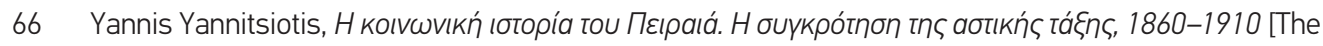
social history of Piraeus: the making of the middle class, 1860-1910] (Athens: Nefeli, 2006).

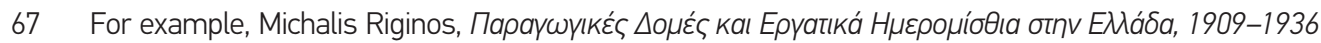
[Structures of production and workers' wages in Greece, 1909-1936], Athens: Commercial Bank of Greece

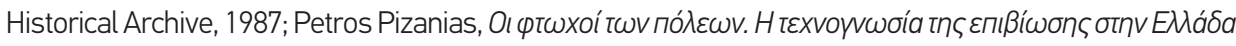

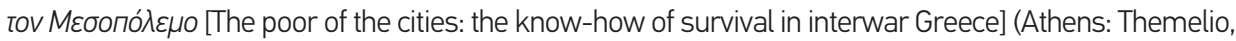

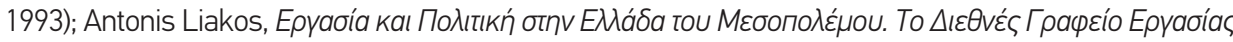

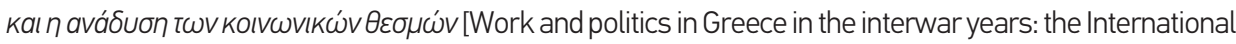
Labour Office and the emergence of social institutions] (Athens: Foundation for Research and Education, Commercial Bank of Greece, 1993 [2nd ed. Nefeli, 2016]). It should be added that Christos Hadziiossif, an advocate of "new history", had referred to the social divisions in the Greek urban centres and the formation of class boundaries in industrial workplaces in the nineteenth and early twentieth centuries, without,

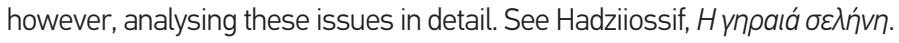

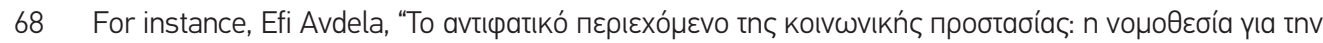

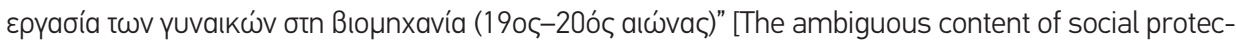
tion: the legislation concerning female labour in industry, 19th-20th centuries], Ta Istorika 11 (1989):

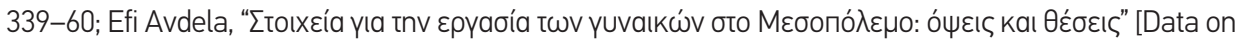

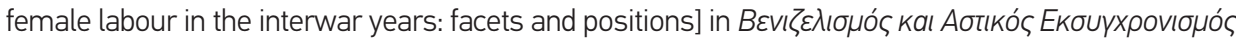
[Venizelism and bourgeois modernisation], ed. Mavrogordatos and Hadziiossif, 193-204; Efi Avdela, $\Delta \eta$ -

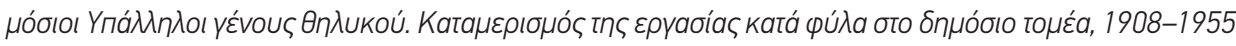
[Female civil servants: work allocation according to gender in the public sector, 1908-1955] (Athens: Foundation for Research and Education, Commercial Bank of Greece, 1990).

69 Although it addressed labour, it was mainly middle-class women that got involved in these feminist initiatives.

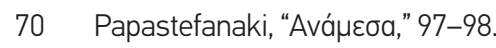

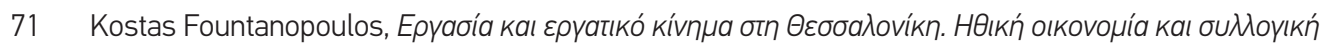

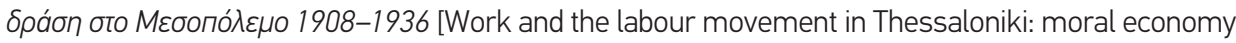
and collective action during the interwar period, 1908-1936] (Athens: Nefeli, 2005); Leda Papastefana-

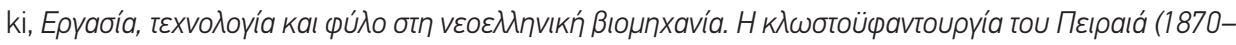
1940) [Labour, technology and gender in the Greek industry: the Piraeus textile industry, 1870-1940] (Iraklio: Crete University Press, 2009). 
73 Papastefanaki was particularly inspired by Joan Scott, Gender and the politics of history (New York: Columbia University Press, 1988).

74 Sonya Rose, Limited livelihoods: gender and class in 19th-century England (London: Routledge, 1992).

75 On population censuses and the participation of women in the workforce, see also Avdela, $\Delta \eta \mu o ́ \sigma ı$ I Yпá $\lambda \eta \lambda$ oı, 16-18. On the unreliability of some sources and the potential of others to uncover the participation of women in the workforce and gender hierarchies at the workplace, see also Papastefanaki,

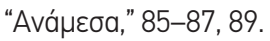

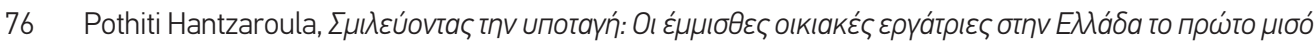

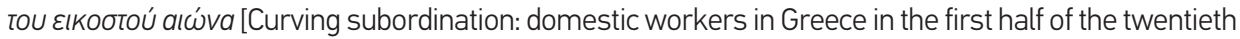
century] (Athens: Papazisis, 2012).

77 On the topic of female domestic workers, but from the perspective of historical demography, see Violetta Hionidou, "Domestic service on three Greek islands in the late 19th and early 20th centuries," History of the Family 10/4 (2005): 473-89.

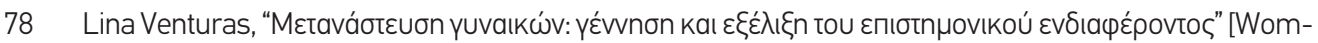
en's migration: inception and development of the scientific interest], in Dini 6 (1993): 230-40.

79 Ioanna Laliotou, Transatlantic subjects: acts of migration and cultures of transnationalism between Greece and America (Chicago: University of Chicago Press, 2004), 110.

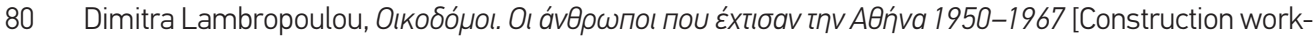
ers: the men who built Athens, 1950-1967] (Athens: Vivliorama, 2009).

81 Kostas Yannakopoulos, “'Naked piazza:' male (homo)sexualities, masculinities and consumer cultures in Greece since the 1960s," in Consumption and gender in southern Europe since the long 1960s, ed. Kostis Kornetis, Eirini Kotsovili and Nikolaos Papadogiannis (London, Bloomsbury, 2016), 296.

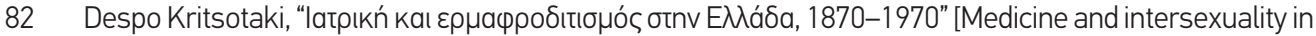

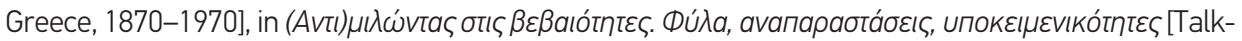
ing (back) to certainties: gender, representations, subjectivities], ed. Dimitra Vassiliadou, Panagiotis Zestanakis, Maria Kefala and Maria Preka (Athens: Group for the Study of History and Society (OMIK), 2013), 198-222.

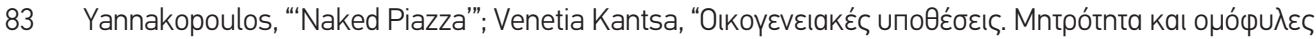

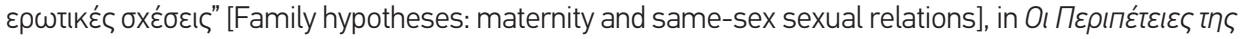

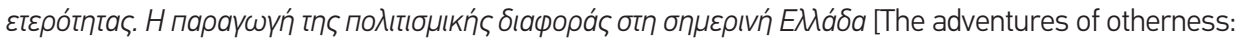
the construction of cultural difference in Greece today], ed. Evthymios Papataxiarchis (Athens: Alexandria, 2006); Elisabeth Kirtsoglou, For the love of women. gender, identity and same-sex relations in a Greek provincial town (London: Routledge, 2004).

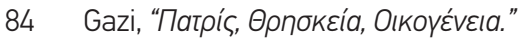

85 Katherine Stefatos, "The psyche and the body: political persecution and gender violence against women in the Greek civil war," Journal of Modern Greek Studies 29 (2011): 251-77; Tasoula Vervenioti, H

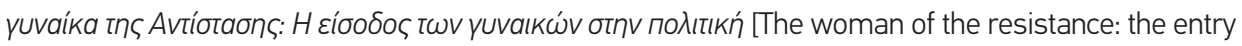

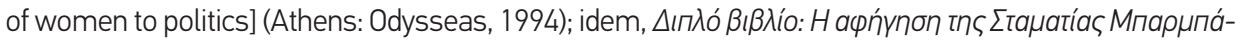

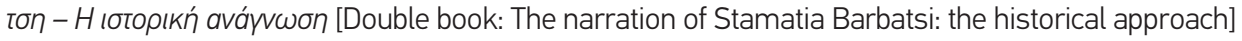
(Athens: Vivliorama, 2003); idem, "Left-wing women between Politics and Family," in After the war was over: reconstructing the family, nation and state in Greece, 1943-1960, ed. Mark Mazower (Princeton: Princeton University Press, 2000), 105-21. 
86 Achilleas Hadjikyriacou, Masculinity and gender in Greek cinema (London: Bloomsbury Academic: 2013).

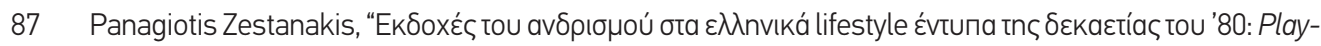
boy, Status, Klik (1985-1990)" [Versions of masculinity in the Greek lifestyle magazines of the 1980s: Playboy, Status, Klik, 1985-1990] (MA diss., University of Crete, 2008).

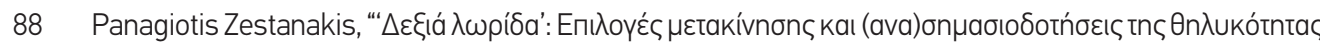

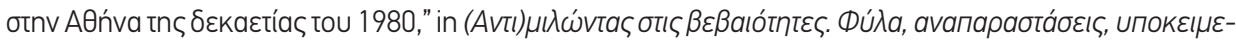
VIKótntєৎ [Talking (back) to certainties: gender, representations, subjectivities], ed. Dimitra Vassiliadou, Panagiotis Zestanakis, Maria Kefala and Maria Preka (Athens: Group for the Study of History and Society (OMIK), 2013), 176-94.

89 For a volume considering the spatial turn in approaching gender in Greece, see Kostas Yannakopoulos

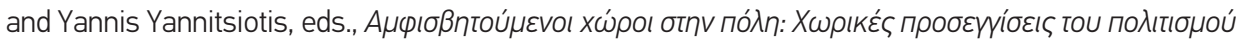
[Contested urban spaces: spatial approaches to culture] (Athens: Alexandria, 2010). In a sense, however, the making of space and its link to gender hierarchies and identities was a topic raised by gender historians in Greece from the outset and without reference to the spatial turn, when they challenged, for instance, the association of the "public" with men and of the "private" with women.

90 Margaret Poulos, Arms and the woman: just warriors and Greek feminist identity (New York: Columbia University Press, 2009).

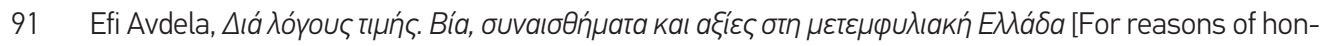
our: violence, emotions and values in the post-civil war Greece] (Athens: Nefeli, 2002).

92 Relevant anthropological work includes: John K. Campbell, Honour, family and patronage: a study of institutions and moral values in a Greek mountain community (Oxford: Clarendon Press, 1964); Ernestine Friedl, Vassilika: A village in modern Greece (New York: Holt, Rinehart and Winston, 1962). On Yannitsiotis' remark, see Yannitsiotis, "Social history," 123.

93 Anthropologist William Reddy argues that "the complex of practices that establish a set of emotional norms and that sanction those who break them I call emotional regime". See: William M. Reddy, The navigation of feeling: a framework for the history of emotions (Cambridge and New York: Cambridge University Press, 2001), 322-23.

94 Evdoxios Doxiadis, The shackles of modernity: women, property, and the transition from the Ottoman empire to the Greek state, 1750-1850 (Cambridge: Harvard University Press, 2012).

95 Ibid., 257.

96 See the publications of the Historical Archive of Greek Youth, http://www.iaen.gr/books.html.

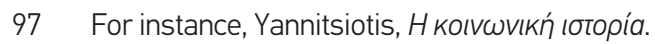

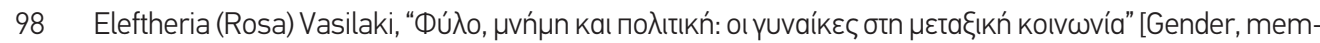
ory and politics: women in Metaxas' society], Ta Istorika 48 (2008): 79-102.

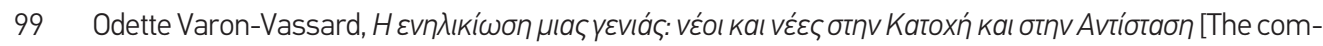
ing of age of a generation: young men and women in the occupation and the resistance] (Athens: Estia, 2009).

100 Efi Avdela, “'Corrupting and uncontrollable activities': moral panic about youth in post-civil-war Greece," Journal of Contemporary History 43:1 (2008): 25-44.

101 Luisa Passerini, "Youth as a metaphor for social change: Fascist Italy and America in the 1950s," in A 
History of Young People in the West, vol. 2, ed. Giovanni Levi and Jean-Claude Schmitt (Cambridge: Harvard UP, 1997), 281-340.

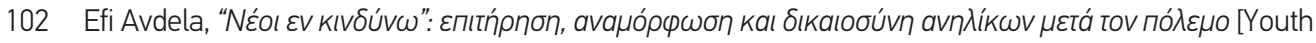
in danger: custody, rehabilitation and juvenile justice after the war] (Athens: Polis, 2013).

103 For instance, Kostas Yannakopoulos, "Amis ou amants? Amours entre hommes et identités sexuelles au Pirée et à Athènes," Terrain 27 (1996): 59-70.

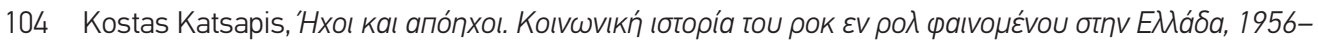
1967 [Sounds and echoes: a social history of the rock 'n' roll phenomenon in Greece, 1956-1967] (Athens: Historical Archive of Greek Youth, 2007).

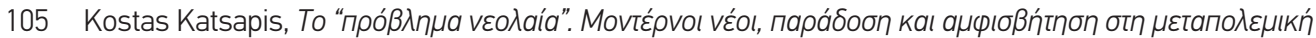
EMáda, 1964-1974 [Youth as a "problem": modern youth, tradition and challenging in postwar Greece, 1964-1974] (Athens: Aprovleptes, 2013).

106 Kostis Kornetis, Children of the dictatorship: student resistance, cultural politics and the "long 1960s" in Greece (New York: Berghahn, 2013).

107 Arthur Marwick, The sixties: cultural revolution in Britain, France, Italy and the United States, c. 1958-c. 1974 (Oxford: Oxford University Press, 1998).

108 Kornetis, Children of the dictatorship, 207.

109 Nikolaos Papadogiannis, Militant around the clock? Left-wing youth politics, leisure and sexuality in post-dictatorship Greece, 1974-1981 (Oxford: Berghahn, 2015); idem, “Confronting 'imperialism' and 'loneliness': sexual and gender relations among young communists in Greece, 1974-1981," Journal of Modern Greek Studies 29 (2011): 219-50; Nikolaos Papadogiannis and Sebastian Gehrig, "'The personal is political': sexuality, gender and the left in Europe during the 1970s," European Review of History 22/1 (2015): 1-15.

110 Kevin P. Murphy and Jennifer M. Spear, "Introduction," in Historicizing gender and sexuality (Oxford: Wiley-Blackwell, 2011), 1-11

111 Eurocommunist organisations advocated political pluralism and were to a greater or lesser extent critical of the USSR in terms of the implementation of communist ideology. Eurocommunism, according to Tony Judt, was given official currency by the general secretary of the Communist Party of Spain, Santiago Carrillo, in his 1977 essay Eurocomunismo y Estado [Eurocommunism and the state]. See Tony Judt, Postwar: a history of Europe since 1945 (London: Vintage, 2007), 495-96, 550.

112 Papadogiannis and Gehrig, "The personal is political." 